\title{
The Improvement of a Thai Organic Rice Supply Chain: A Case Study of a Community Enterprise
}

\author{
Yaniga Prasertwattanakul ${ }^{1}$ and Pornthipa Ongkunaruk ${ }^{* 1}$ \\ ${ }^{1}$ Department of Agro-Industrial Technology, Faculty of Agro-Industry, Kasetsart University \\ 50 Ngam Wong Wan Rd. Lad Yao, Chatuchak, Bangkok 10900 Thailand \\ Email: pornthipa.o@ku.ac.th*
}

\begin{abstract}
The demand for organic product has been increasing for decades due to consumer consciousness for health and environment. In Thailand, the volume of organic rice production is increasing, especially for the community enterprises. Our objectives are to explore the supply chain of a community enterprise in Uthai Thani, to analyze the business process and identify the problems and to provide the recommendation for an efficiency improvement. Then, we conduct an in-depth interview to gain better understanding of farmer and the community enterprise. Next, the business process analysis is analyzed using Integration Definition for Function Modeling (IDEF0). For farmers and the community enterprise, the key performance indicators are productivity, cost and quality. Then, the proper controls and mechanisms are proposed. These could be the direction for further development to enhance organic rice supply chain management for Thai producers especially smallholders to penetrate the international and domestic markets.
\end{abstract}

Keywords: Business Process Analysis; Community Enterprise; IDEF0; Organic Rice; Supply Chain Management

\section{INTRODUCTION}

Over the past decades, rice plays an important role for Thai people. It is not only the main food but also includes other aspects of Thai lifestyles, beliefs, traditions and cultures. Moreover, rice is the major export product of value over billions US dollars per year. However, in 2002, the value of exports has decreased, due mainly to the impact of bilateral FTAs and the introduction of strict food safety and traceability legislation by EU and other importing countries. Therefore, compliance with these regulations is essential for new and existing Thai exporters and smallholder farmers (Lorlowhakarn et al., 2008). The organic rice farming in Thailand has been cultivated for self-consumption since 1992 (Sribrikit, 2011). At present, due to the increasing trend of consumer consciousness of health, safety and environmental issues as well as the emerging markets, Thai exporters, cooperatives and smallholder farmers have realized increasing demand consumption. However, the certification system starting from rice farming and processing must be certified by the customers' standard. In 2013, there are 125,730.71 rais certified organic rice farms with increasing from 124,964.39 rais in 2012 (Panyakul, 2015), of which produced total 44,005.8 tons, valued at 704.1 million Baht (Green Net, 2015). The cultivated area in 2013 was increased by $0.61 \%$ from 2012 (Bureau of Rice Trade Administration, 2014).

Our objectives are first, to explore organic rice supply chain of a community enterprise in order to sustain the product quality and productivity by scoping the area of interest at Uthai Thani province in central Thailand. Second, to analyze its business process and identify the problem of organic rice supply chain focusing on farmers and the community enterprise by drawing in form of IDEF0. Finally, to provide the recommendation and opportunity to improve efficiency of Thai organic rice supply chain.

\section{METHODOLOGY}

In this study, we conduct an in-depth interview with the leader of the community enterprise, named Ban Nong Waen using questionnaire as a tool to explore the organic rice supply chain. The questions compose of

ISSN 2413-0877 (C) 2016 The Authors.

Published by KnowledgeE Publishing Services. This is an open access article under the CC BY-NC-ND license (http://creativecommons.org/licenses/by-nc-nd/4.0) 
demographic data and key activities such as planning, sourcing, production, delivery, and return. Then, we analyz a business process of farmers and the community enterprise using Integration Definition for Function Modeling (IDEF0). IDEF0 is designed to model the activities of an organization or system (IDEF, 2014). These activities are represented by square boxes with a code at the right corner in order to indicate the rank of each activity such as A1, A2 and A3. Activities can be described by their inputs, outputs, controls and mechanisms which represented by four types of arrows. First, the input arrow denotes the material and information that drive the activity, represented by the arrow entering into the activity box on the left. The second arrow signifies the output or the material or information created by the activity, represented by the arrow leaving the activity box on the right. The third arrow is the control, which is the standard, regulation, or requirement of the activity, represented by the arrow entering from the top. Finally, a mechanism arrow implies the resources such as people, machines and/or equipment that used to perform the activity, represented by the arrow entering into the bottom of the activity box (Ongkunaruk, 2015). In addition, a solid line specifies the current activities and a dashed line identifies the improvement that we suggested after analyzing the business process in order to improve the organic rice supply chain management. Finally, we propose the guideline to improve the efficiency for farmers and the enterprise.

\section{RESULTS}

\subsection{Background of Ban Nong Waen Community Enterprise}

Ban Nong Waen community enterprise is formed by a farmer group located in Uthai Thani province. At present, there are twenty members with the president name Miss Prapaisri Munketkit. The goal of founding the enterprise is to encourage members to stop using chemical substances and fertilizers that cause health problems to both farmers and consumers and substituting by organic rice farming. Moreover, the organic farming can reduce production cost, especially for chemical substances and fertilizers. In a long term, the organic farming help farmers having more savings, lower debts, good health and clean environment which lead them to have a sustainable living.

Total certified organic rice farm area of the enterprise is 65 rais. In 2014, it produced 32 tons of paddies and generated 576,000 Baht. Sixty percent of net profit is for cash dividend, twenty percent is reserved for operating expenses, ten percent is for members' benefits, and ten percent is for social charity such as disaster recovery, traditional festival in community, etc. The group has a strong commitment to produce the organic rice and strictly follows the guidelines provided from the government officers. Later, the group was certified by the Organic Thailand certification from the Department of Agriculture since 2005. However, at present the certification authority for rice has transferred to the Rice Department. After that, the group expands rice cultivated area and has an investment plan to integrate their local rice mill and packing house to control the quality throughout the supply chain.

\subsection{Overview of an Organic Rice Supply Chain for Community Enterprise}

The organic rice supply chain of the community enterprise is shown in Figure 1. First, farmers cultivate organic rice according to Organic Thailand Standard (TAS 9000 part 1 - 2009 and TAS 9000 part 4 - 2010) certified by Rice Department. Unlike other farms in central region, this community farm is cultivated under rain fed areas. Therefore, farmers can produce only one crop per year during rainy season and will harvest after four or five months. During harvest season, the paddies contain moisture more than $20 \%$. This condition induces mold growth and the paddies will be deteriorated. Hence, the sun drying of paddy for a few days is necessary process to reduce the moisture down to $14 \%$ which is safe for storing paddy. However, most farmers do not have the moisture meter to measure the paddy moisture content. We found that sometimes paddy has moisture content less than the standard and this is one kind of waste. After that, some farmers sell paddy to community enterprise, but some mill and sell by themselves as shown by a dashed line in Figure 1. Farmers who sell paddies to the enterprise gain higher price than general market price. At the enterprise, most operations run by the president of the group. 
Next, the paddies are kept at members' barns due to no central warehouse. Then, the paddies will be delivered to the local rice mill which is the property of the enterprise upon the orders from local customers. On the other hand, for premium rice, the paddies will be outsourced to a high quality rice mill due to the limitation of the capacity, technology and hygiene of the enterprise milling machine. After milling by the enterprise, farmers obtain only head rice and broken rice, but the husk belongs to the enterprise. Later, rice will be separated to head rice and broken rice by a rotary sifter. On the other hand, the outsourcing rice mill has already separated head rice and broken rice, therefore rice can be graded by removing defects such as damaged kernels, stones and other impurities. The last two steps are vacuum packing and labeling before delivery to customers who are local retailers and end consumers. The Organic Thailand logo on a package represents the certification of farming, processing and packing of organic rice. Failure to any qualification will prohibit to labeling Organic Thailand logo. However, currently milling and packing process of the enterprise and the outsourcing rice mill have not been certified under the organic processing by Rice Department yet.

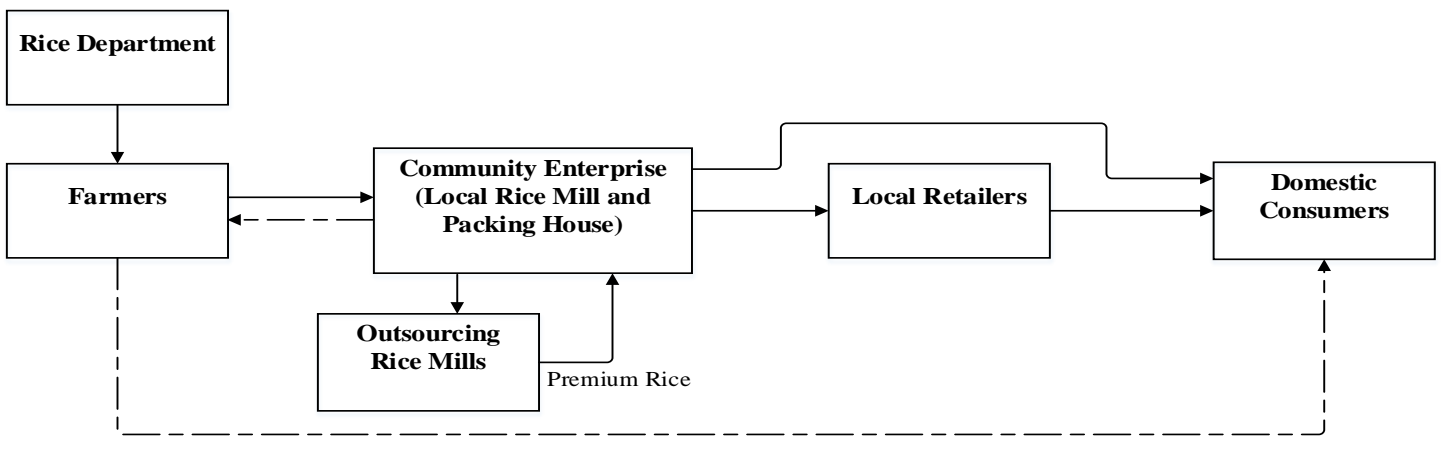

Figure 1 . An organic rice supply chain for community enterprise

\subsection{Business Process Analysis of an Organic Farmer}

The activities of farmers are shown in Figure 2. Farmers plan to allocate the land and select the varieties of rice to produce based on last year sales volume and the current demand. However, farmers should determine which rice variety is suitable based on cost and benefit. One of the most important factors for rice cultivation is stable water resource. However, the rainfall is unpredictable and it is a high risk for cultivation under rain fed. The rainfall impacts the planting schedule and productivity of rice. Therefore, the implementation of risk management is necessary for farmers to prevent risk occurring or minimize its negative impact. For sourcing inputs, farmers should plan to select the best quality of rice seeds, fertilizers, organic substances to remove pest and disease. Farmers should know which methods and substances can increase the rice yield. Most of them using trials and errors, hence, the knowledge management by training, data collection and analysis and sharing information could increase organic farming productivity. Currently, farmers often use seeds that they select from the previous crop. In the future, the high quality rice mill should be established in a central location because currently one of outsourcing rice mill is located in another province. Additionally, we suggest that farmers should define key performance indicators (KPIs) for main activities to identify and control the farm performance and profitability. For example, production cost, productivity and transportation cost. Finally, we summarize the current problems and recommendation for farmers in Table 1.

\subsection{Business Process Analysis of the Community Enterprise}

The activities of the community enterprise which has a small-sized rice mill and a packing house are shown in Figure 3. The production plan is figured based on the historical data and is adjusted by the current trend. The enterprise purchases only paddies 
from certified Organic Thailand farms. However, due to a limitation number of certified organic farms and low productivity, the rice volume some time is not met the demand. In addition, the enterprise has certain criteria to determine the price of paddies i.e. moisture content and head rice yield. At present, there is no standard measurement of the moisture content, but using handfeel and physical inspection which depends on experience and skill over seventeen years. We suggest that the enterprise should record paddy amount, moisture content and head rice yield for each farmer so that they can use these information to evaluate supplier performance and improve the quality of farmers. In addition, for milling and packing, we suggest that they should implement Total Preventive Maintenance (TPM) in order to increase the efficiency of machines and kaizen to reduce wastes occurred during machine start-up and break down. In return process, we found that leak package is the major cause. Hence, the enterprise should study the root causes of leaking and determine the optimal condition of vacuum packing or consult the expert. Next, the key performance indicators such as production cost, lead time and defective proportion should be included. The summary of the problems and recommendation is shown in Table 2.

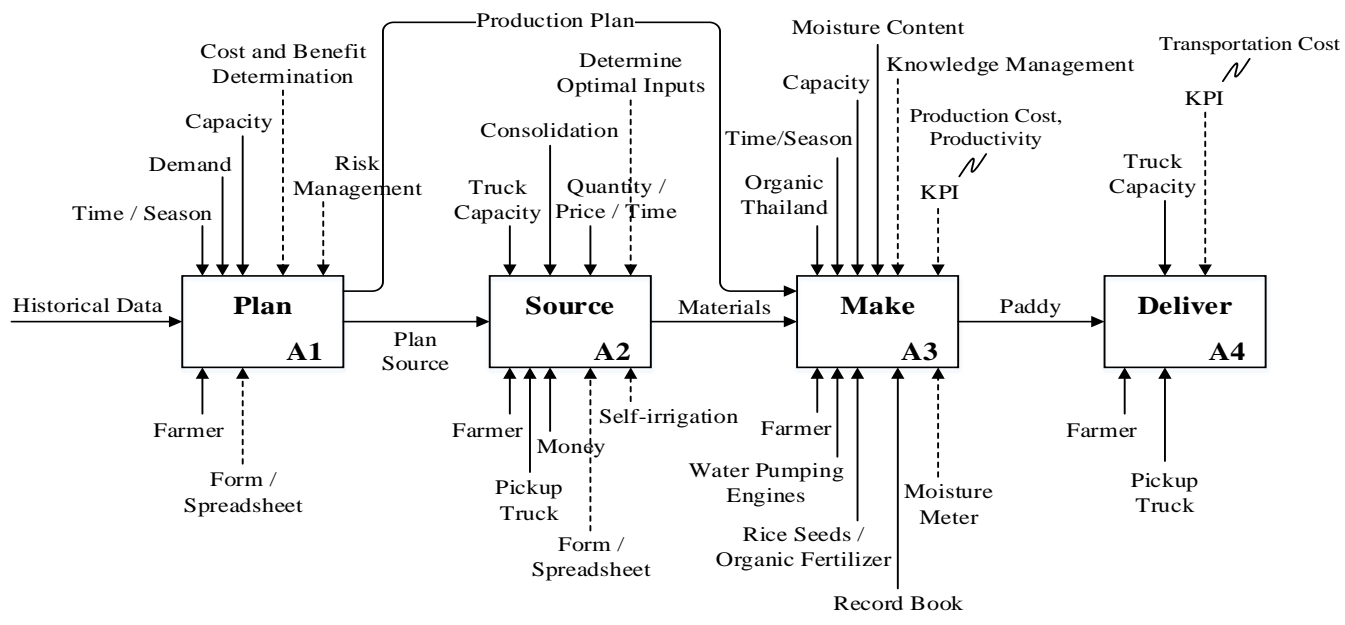

Figure 2. The business process of an organic farmer (IDEF0 level 1)

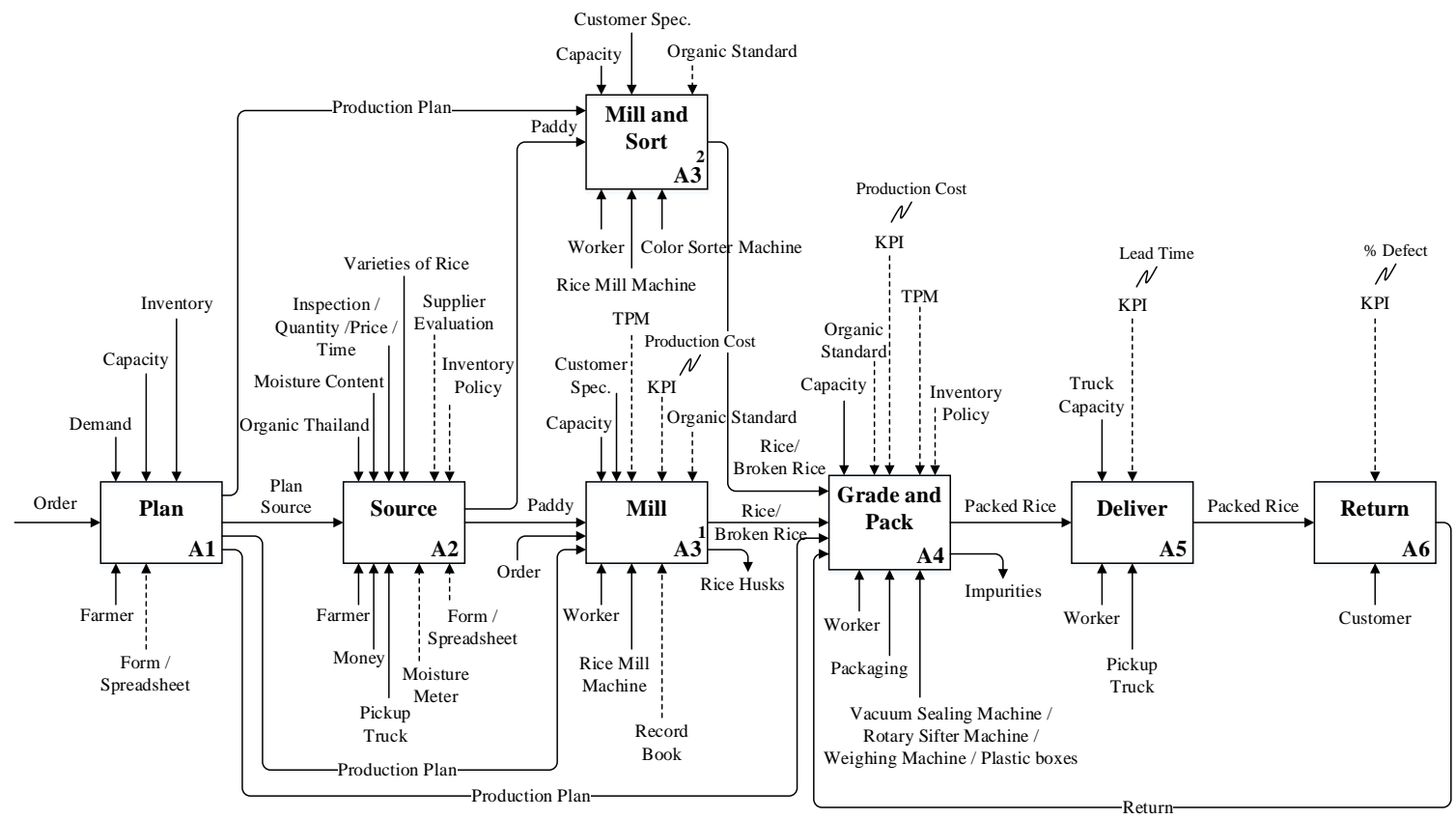

Figure 3. The business process of the community enterprise (IDEF0 level 1) 
Table 1. Summary of problems and recommendation for organic farmers

\begin{tabular}{|l|l|l|}
\hline Activities & Problems & Recommendation \\
\hline Plan & $\begin{array}{l}\text { No risk } \\
\text { management }\end{array}$ & $\begin{array}{l}\text { - Implement risk } \\
\text { management }\end{array}$ \\
\cline { 2 - 3 } & $\begin{array}{l}\text { Lack of } \\
\text { production } \\
\text { planning }\end{array}$ & $\begin{array}{l}\text { - Make a suitable } \\
\text { production plan }\end{array}$ \\
\hline Source & Rely on rainfall & $\begin{array}{l}\text { - Prepare farm } \\
\text { irrigation by } \\
\text { digging the pond }\end{array}$ \\
\cline { 2 - 3 } & $\begin{array}{l}\text { Lack of } \\
\text { selection the } \\
\text { optimal inputs } \\
\text { for farming }\end{array}$ & $\begin{array}{l}\text { - Training } \\
\text { - Determine optimal } \\
\text { inputs }\end{array}$ \\
\hline Make & $\begin{array}{l}\text { Lack of } \\
\text { moisture meter }\end{array}$ & $\begin{array}{l}\text { - Provide a common } \\
\text { moisture meter }\end{array}$ \\
\cline { 2 - 3 } & Low yield & $\begin{array}{l}\text { - Using the optimal } \\
\text { inputs, data } \\
\text { collection, } \\
\text { knowledge } \\
\end{array}$ \\
& & $\begin{array}{l}\text { management } \\
\text { - Define suitable } \\
\text { KPIs }\end{array}$ \\
\hline Deliver & $\begin{array}{l}\text { High } \\
\text { transportation } \\
\text { cost }\end{array}$ & $\begin{array}{l}\text { - Establish high } \\
\text { quality rice mill in } \\
\text { a central location }\end{array}$ \\
\hline
\end{tabular}

Table 2. Summary of problems and recommendation for the community enterprise

\begin{tabular}{|l|l|l|}
\hline Activities & Problems & Recommendation \\
\hline Source & $\begin{array}{l}\text { No standard } \\
\text { moisture content } \\
\text { measurement }\end{array}$ & $\begin{array}{l}\text { - Buy a standard } \\
\text { moisture meter }\end{array}$ \\
\cline { 2 - 3 } & $\begin{array}{l}\text { Lack of } \\
\text { recording data }\end{array}$ & $\begin{array}{l}\text { - Keep record data } \\
\text { in a form or } \\
\text { spreadsheet } \\
\text { - Farmer evaluation }\end{array}$ \\
\hline Make & $\begin{array}{l}\text { Local mill could } \\
\text { not meet the } \\
\text { organic standard }\end{array}$ & $\begin{array}{l}\text { - TPM/Kaizen } \\
\text { - Define suitable } \\
\text { KPIs }\end{array}$ \\
\hline Return & $\begin{array}{l}\text { Leak vacuum } \\
\text { package }\end{array}$ & $\begin{array}{l}\text { - Study the cause of } \\
\text { leaking and } \\
\text { experiment the } \\
\text { right condition for } \\
\text { packing }\end{array}$ \\
\hline
\end{tabular}

\section{CONCLUSION}

The organic rice supply chain of Ban Nong Waen Community Enterprise in Uthai Thani, Thailand consists of six major stakeholders i.e. farmers, the community enterprise, outsourcing rice mills, local retailers, consumers and Rice Department. Next, we analyze the business process of farmers and the community enterprise based on IDEF0 level 1. Then, we identify the missing controls and mechanisms in each activity for farmers and community enterprise such as key performance indicators. Using quality seed and appropriate production techniques such as biomaterials, water management, measuring the moisture content of paddies before selling, record yield and cost of activities could increase the productivity. In addition, to strengthen the community enterprise, all members must have teamwork, trust and participation in group activities through the consolidation of main activities such as planning, sourcing inputs, growing, harvesting, storing, and delivery. In the future, other community enterprises should improve their organic rice supply chain management to increase the competitiveness in domestic and prepare for international markets.

\section{ACKNOWLEDGEMENT}

The authors would like to thank the farmers and the president of the community enterprise who kindly provided information for this research.

\section{REFERENCES}

Bureau of Rice Trade Administration. 2014. The Situation of Organic Rice in Thailand. (http:// www.organic.moc.go.th/sites/default/files/atta chments/import_export/sthaankaarnkhaawinthr iiyaithy.pdf). Accessed on September 4, 2015.

Green Net. 2015. Organic Market in Thailand. (http://www.greennet.or.th/article/1009). Accessed on September 4, 2015.

IDEF. 2014. Function Modeling Method. (http://www.idef.com/IDEF0.htm). Accessed on September 1, 2015.

Lorlowhakarn, S., K. Boonyanopakun, W. Ellis, V. Panyakul, D. Vildozo, A. Kasterine. 2008. Strengthening the Export Capacity of Thailand's Organic Agriculture. (http://www. nia.or.th/organic/download/Strengthening_new .pdf). Accessed on September 3, 2015.

Ongkunaruk, P. 2015. Business process analysis and improvement for a raw milk collection centre in Thailand. Agriculture and Agricultural Science Procedia, 3: 35-39.

Panyakul, V. 2015. Overview of Organic Agriculture in Thailand during 2013-2014. (http://www.greennet.or.th/sites/default/files/ Thai\%200A\%2013-14.pdf). Accessed on September 4, 2015.

Sribrikit, S. 2011. The Situation of Organic Agriculture. (http://www.oae.go.th/ewtadmin/ ewt/oae_baer/download/article/article_201110 13102515.pdf). Accessed on September 5, 2015. 